\title{
Estimation of Genetic Parameters for 305 Days Milk Yields and Calving Interval in Xinjiang Brown Cattle
}

\author{
Xuefeng Fu ${ }^{1 *}$, Lili Lu${ }^{1 *}$, Xixia Huang2\#, Yachun Wang3\#, Kechuan Tian1', Xinming Xu${ }^{1}$, Jiqing Fang ${ }^{4}$, \\ Liming Cheng', Zhiqin Guo', Yuezhen Tian'
}

\author{
${ }^{1}$ Xinjiang Academy of Animal Sciences, Urumqi, China \\ ${ }^{2}$ College of Animal Science, Xinjiang Agricultural University, Urumqi, China \\ ${ }^{3}$ College of Animal Science \& Technology, China Agricultural University, Beijing, China \\ ${ }^{4}$ Xinjiang Animal Husbandry Service, Urumqi, China \\ ${ }^{5}$ Xinjiang Urumqi Cattle Breeding Farm, Urumqi, China \\ Email: "au-huangxixia@163.com, "wangyachun@cau.edu.cn
}

How to cite this paper: Fu, X.F., Lu, L.L., Huang, X.X., Wang, Y.C., Tian, K.C., Xu, X.M., Fang, J.Q., Cheng, L.M., Guo, Z.Q. and Tian, Y.Z. (2017) Estimation of Genetic Parameters for 305 Days Milk Yields and Calving Interval in Xinjiang Brown Cattle. Agricultural Sciences, 8, 46-55. http://dx.doi.org/10.4236/as.2017.81004

Received: August 23, 2015

Accepted: January 8, 2017

Published: January 11, 2017

Copyright $\odot 2017$ by authors and Scientific Research Publishing Inc. This work is licensed under the Creative Commons Attribution International License (CC BY 4.0).

http://creativecommons.org/licenses/by/4.0/

(c) (i) Open Access

\begin{abstract}
This study was conducted to estimate variance components and genetic parameters for 305 days mature equivalent milk yields (MEM) and calving interval (CAI) of registered Xinjiang Brown cattle. The total records were 3940 including 2579 for 305-day MEM and 1970 for CAI, which were collected from Xinjiang Urumqi Cattle Breeding farm in China with calving records from 1990 to 2008. Genetic parameters were obtained by multiple trait derivative-free restricted maximum likelihood (MTDFREML) using animal model. The model included year, season, parity and calving interval of calving for 305 days MEM, and year, season and parity of birth for CAI as fixed effects. Heritability for 305 days MEM was moderate (0.39) and in the same range of parameters estimated in management systems with medium production levels. Heritability of calving interval was small (0.02) as fertility traits for Xinjiang Brown cattle. Estimates of genetic and environmental correlations between 305 days MEM and CAI were 0.47 and 0.37, respectively. Estimates of genetic variation and heritability indicated that selection would result in genetic improvement of production traits. Estimates of both heritability and genetic variation for CAI were small, which indicates that genetic improvement would be difficult.
\end{abstract}

\section{Keywords}

Genetic Parameter, 305 Days MEM, Calving Interval, Xinjiang Brown Cattle

\section{Introduction}

The Xinjiang Brown cattle belong to the dual-purpose cow. As early as in 
1935-1936, the Brown Swiss were introduced into China from abroad, and the local Kazakh cattle of Xinjiang region were hybridized by Brown Swiss since then. In order to improve production performance of the local Kazakh cattle, the Allah itau cattle and Costello cattle were successively introduced from the former Soviet union in 1951-1956, and three groups of Brown Swiss, frozen semen and embryo were again introduced from West Germany and Austria in the years 1977 and 1980. In the 1983, the Department of Animal Husbandry of Xinjiang Uygur Autonomous Region had organized experts to do the certification varieties work in China, and the improved Kazakh cattle has passed the examination and approval of the varieties; the experts claimed that the improved Kazakh catthe is a dual-purpose of indigenous breed, and it has good cold resistance, resistance to coarse feeding and strong adaptability characteristic after long-term breeding and acclimatization. At present, the amount of livestock on hand is more than 200 thousand head, and average milk production of one lactation period is $6000 \mathrm{~kg}$ for milking cows [1].

The population parameter estimation of quantitative character was indispensible for animal quantitative genetics and breeding. It is necessary that genetic parameter was estimated for the important economic trait in dairy cattle, and it has great significance for drawing up breeding scheme, implementing efficient breeding programs, predicting selection effect and explaining genetic mechanism in large-scale dairy farm [2]. On the one hand, the researcher can apply phenotypic value to deduce and estimate breeding value. On the other hand, they would establish selection index and estimate genetic progress in animal breeding plan [3]. There was much room for improvement in methodology applied for genetic evaluations [4]. For instance, accurate heritability and genetic correlation estimates are required to predict expected selection response and to obtain predicted breeding values using animal mixed model and best linear unbiased prediction (BLUP) programs [2]. Traits related to milk production, fertility and health are included in breeding programs of dairy cattle in many countries, in order to maximize improvement of a breeding goal involving traits related to income and costs [2] [4] [5]. Therefore, it is beneficial to improve population genetic progress and breeding effect when genetic parameter was accurately estimated [2] [4] [5] [6] [7]. A measure of lactation yield is information needed for management and genetic evaluation in dairy cattle; hence monthly test day yields are used as basis for calculating whole lactation yields [8]. Lactation totals and lactation to-date totals must be calculated using an ICAR approves method. The test interval method (TIM) has become a standard method for this purpose; it is currently used to calculate dairy herd improvement (DHI) lactation and lactation-to-date totals [9]. The test interval (number of days from the previous test day through the current test day) is divided into two equal portions. Production credits for the first half of the test interval are calculated from the current test day information. The totals for the two portion of the test interval are added to obtain the interval totals. 
Due to the fact that the milk production was important economic traits for dairy cattle, the estimates of genetic parameters are significant in the actual production. Recently, no published report was found on estimates of genetic parameters for milk production and fertility traits in Xinjiang Brown cattle. Therefore, the objective of this study was to estimate genetic parameters of 305 days mature equivalent milk yields and calving interval for Xinjiang Brown cattle in China, it will provide a theoretical basis for drawing up and optimizing breeding plan, improving genetic constitution and developing new varieties of high quality, high yield and meeting the social needs in future.

\section{Materials and Methods}

\subsection{Data and Edits}

Data on 3940 records of Xinjiang Brown cattle between 1990 and 2008 were collected from the Xinjiang Urumqi Cattle Breeding farm in China. The records were excluded that days in milk is greater than 305 days or less than 10 days, lactation yields less than $0.5 \mathrm{~kg}$, TIM greater than 60 days, less than 5 times in lactation totals, suffering cow in lactation, respectively. Analytical traits are 305 days mature equivalent milk yields and subsequent calving interval. Almost all lactations were milked in either 2 or 3 times/d during the whole 305 days period.

Records for 305 days complete lactations were projected by TIM. Incomplete lactations for 100 to 304 days in milk (DIM) were adjusted to 305 days using methods according to functions of the last sample productions [10]. Paired comparison coefficients were utilized to calculate mature age milk yields, and mature equivalent 305-day milk production values were used for variance analysis and genetic parameter estimation. Records of nonregistered animals and those with unknown sires or dams were excluded from the analysis. Permissible values in the recording system were less than $9867 \mathrm{~kg}$ for 305 days MEM, and ranged from 237 to 706 days records for CAI. To exclude possibly erroneous records, lactation records less than or greater than 3 SD from the mean for MEM and was not used.

The final data base included valid records 3940 and animals with valid records 2579 for 305 days MEM and 1970 for CAI. Animals in the pedigree file were born between 1990 and 2008. Characteristics of the data set were given in Table 1.

\subsection{Model and Analysis}

Four fixed effects of year, season, parity and calving interval for 305 days MEM

Table 1. Descriptive statistics of data.

\begin{tabular}{ccccccc}
\hline Trait & N & Mean & SD & CV (\%) & Min & Max \\
\hline MEM (Kg) & 2579 & 4994.55 & 1018.59 & 20.39 & 2242.8 & 9867.3 \\
CAI (day) & 420.994 & 392.792 & 83.1045 & 19.74 & 237.00 & 706.00 \\
\hline
\end{tabular}


were included in the model. In accordance with the calendar year, the year effect was taken into account model. Calving months were divided into four groups by spring (March to May), summer (June to August), autumn (September to November) and winter (December to February) on the basis of climate characteristics of Xinjiang in China, respectively. Parity factors were occurred at 6 level groups by $1^{\text {st }}$ parity, $2^{\text {nd }}$ parity, $3^{\text {rd }}$ parity, $4^{\text {th }}$ parity, $5^{\text {th }}$ parity, $6^{\text {th }}$ parity and above, respectively. The calving intervals were considered at 6 level groups by $330 \mathrm{~d}$ and under, $331 \mathrm{~d}-359 \mathrm{~d}, 360 \mathrm{~d}-389 \mathrm{~d}, 390 \mathrm{~d}-419 \mathrm{~d}, 420 \mathrm{~d}-500 \mathrm{~d}$, and more than 500d, respectively. However, the effects of year, season and parity of birth were statistically evaluated for CAI using the model adopted under investigation (Table 2).

Genetic parameters and variance components for investigated traits were estimated by Multiple Trait Derivative-Free Restricted Maximum Likelihood (MTDFREML) using animal model with the help of a manual for use of MTDFREML [11]. The model included random animal genetic effects and maternal effect. The mixed model matrix form:

$$
y=X b+Z u+e
$$

where $y$ is the vector of records for MEM and CAI; $b$ is the vector of fixed effects containing the effects of year, season, parity and calving interval of calving for 305 days MEM, and year, season and parity of birth for CAI; $u$ is the vector of random animal effects, including animals without records; $e$ is the vector of random residual effects; $X$ and $Z$ are incidence matrices assigning observations to fixed and random animal effects, respectively. Starting values for elements of variance genetic and environmental matrices were estimates obtained from preliminary single trait model analyses and from assumed correlations.

\section{Results and Discussion}

Descriptive statistics for the variables studied are shown in Table 1. The estimates of additive genetic and phenotypic variances as well as the heritability of the traits evaluated for breeding purpose were given in Table 3. From Table 4, different additive genetic variation was observed for analyzing traits records, the heritability of 305 days MEM and CAI were 0.39 and 0.02 , and genetic and environmental correlations were 0.47 and 0.37 , respectively.

\subsection{Heritability Estimates}

Heritability of 305 days MEM was estimated by 0.39 for Xinjiang Brown cattle

Table 2. Level grouping of fixed effects.

\begin{tabular}{ll}
\hline Fixed Effect & Level \\
\hline Season & 4 (Spring, Summer, Autumn, Winter) \\
Parity & $6(1,2,3,4,5, \geq 6)$ \\
Calving interval & $6(\leq 330,331-359,360-389,390-419,420-500, \geq 501)$ \\
\hline
\end{tabular}


Table 3. Estimates of variance components for the evaluated traits.

\begin{tabular}{cccc}
\hline Traits & Genetic Variances & Environmental Variances & Phenotypic Variances \\
\hline MEM & 306971.073 & 470598.729 & 4088.325 \\
CAI & 67.067 & 777569.802 & 4155.391 \\
\hline
\end{tabular}

Table 4. Heritabilities (on diagonal), genetic (above) and environmental correlations (below) for MEM and CAI in Xinjiang Brown cattle.

\begin{tabular}{ccc}
\hline Traits & MEM & CAI \\
\hline MEM & 0.39 & 0.47 \\
CAI & 0.37 & 0.02 \\
\hline
\end{tabular}

under the investigation. The presentation estimate was found similar to the previously reported results of heritability from 0.35 to 0.37 for Brown Swiss [12] [13] [14] [15]. This estimate was higher than the earlier estimates of 0.25 to 0.28 reported by most authors by REML method in Brown Swiss cattle [16] [17] [18] [19], and the other workers of 0.27 to 0.36 by REML method in Holstein Friesian cattle [20] [21] [22]. However, it was still higher than the heritability of 305 days milk yield (0.02) and test day milk yields (0.10) for Brown Swiss cows reared at Ulaş State farm [23], and the heritability of milk yield for first lactation (0.23) and all lactations (0.19) for Brown Swiss Reared in the Bahri Dağdaş international agricultural research institute in Turkey [24]. The present result was slightly lower than previously reported results for 305 days MEM and milk in the first 3 lactations $(0.51,0.49$ and 0.47$)$ using the random regression model for large Holstein populations in the Netherlands [25], and the direct heritability of 305 days milk yield before three lactation period were obtained as $0.45,0.42$ and 0.40 using test-day records for Canadian Holsteins [26]. However, the recently reports have shown that the heritability of 305 days mature equivalent milk production was between $0.12 \pm 0.03$ and $0.19 \pm 0.02$ for first and third parity in Mexican Holstein cows [2]. Similarly, heritability of milk yield for all lactations as $0.24 \pm 0.08$ and heritability for first lactation as $0.30 \pm 0.154$ was estimated by many workers for Simmental Cattle in Turkey [27]. Our results are, therefore, in line with expectations according to these studies.

Heritability estimates for CAI was 0.02 for Xinjiang Brown cattle. A large number of literature shows that the relatively small estimates $($ i.e. $<0.10)$ are common for many fertility traits in dairy cows. For example, in a review of estimates used for genetic evaluations of fertility traits worldwide, concluded that fertility traits in dairy cattle populations have heritability of 0.04 or less. They reported the heritability of 0.04 for days open in the US Holstein population [28]. Another review article also shown that the values of the genetic parameters used in several countries for genetic evaluations and the heritability for fertility traits ranged from 0.01 to 0.07 [3]. Present estimates from the current study are similar to previously reported results of heritability from 0.02 to 0.04 in Australia [29], and it is slightly less than estimates from 0.03 to 0.04 by the others work- 
ers in the Netherlands (0.04) [30], United Kingdom (0.03 \pm 0.01$)$ [31], Australian Holstein-Friesian cattle (0.04 - 0.03) [32] and Spain (0.04) [33]. However, it is consistent with the recent research results of heritability estimates for calving interval from 0.01 to 0.02 in Mexican Holstein cows [2].

Differences between the estimates of heritability obtained in this study and estimates from other researchers are most likely caused by research objects, management, climate and different model affecting genetic and environmental variances. Emphasis given to traits in the breeding programs will be dictated by economic and social considerations. The inclusion of traits with small estimates of heritability in progeny testing programs of sires such as calving interval is possible, more daughter records would be necessary for the evaluation of a sire for an index involving production traits.

\subsection{Genetic and Environmental Correlations}

The positive estimates of genetic correlations between 305 days MEM and CAI was observed for this study (0.47). Most other studies have stated the estimates of the genetic correlation between CAI (or days open) and milk yield ranging from 0.10 to 0.67 [28] [32] [34] [35]. This estimate was different to those review showed that the genetic correlation between calving interval and milk yield was -0.2 [36], increased from -0.43 in the first to -0.58 in the second parity [32], and ranging from -0.011 to -0.449 [1], respectively.

In the study, moderate positive estimates of environmental correlations between 305 days MEM and CAI were observed for Xinjiang Brown cattle by this study (0.37) [2]. The related reports shown that estimates of environmental correlation of MEM with CAI were positive ranged from 0.089 to 0.173 in Mexican Holstein cows. Therefore, estimates of the environmental correlations were slightly favorable for Xinjiang Brown cattle.

In general, differences between the results of the present study and those reporting unfavorable genetic relationships for milk yield and fertility traits may be a result of peculiarities of the recorded in Xinjiang Brown cattle, with high environmental factors influencing for milk production [37].

\section{Conclusions}

Estimates of heritability and genetic variation for 305 days MEM in this study were moderate compared with major reports on Brown Swiss, Holstein populations and Simmental cattle. The results indicate that response to selection would be expected in Xinjiang Brown cattle. Estimates of heritability and genetic variation for CAI were smaller so that response to selection would be more difficult to obtain than for 305 days MEM trait. However, parameter estimates were in the same range of previous results obtained in other studies of data from management systems belonging to medium production levels. Low heritability estimates are caused by reduced additive genetic and increased permanent environmental and residual variances.

Estimate of genetic correlation between 305 days MEM and CAI within all 
lactations was 0.47 , high and favorable in general. Estimate of environmental correlation was 0.37 , large and favorable between 305 days MEM and CAI. Estimates of variance components found in this study may be used for the implementation of a BLUP evaluation for Xinjiang Brown cattle. Although, the differences in the results for calving interval relative to 305 days mature equivalent milk yield should be further investigated, data quality management might be still an important issue for this trait. These parameter estimates can be used to design better breeding programs for Xinjiang Brown cattle population involving an economic index of production traits and fertility traits for ranking of sires. In addition, relative economic values of each trait for local markets are needed for simultaneous selection of these traits and others of economic importance.

\section{Acknowledgements}

This study data was provided by the Xinjiang Urumqi Cattle Breeding farm in China. The authors are thankful to Xixia HUANG for providing the MTDFREML program and proofreading the manuscript, and to Kechuan TIAN for many useful suggestions for improving the manuscript.

\section{Data Availability Statement}

All relevant data are within the paper.

\section{Funding}

This work was supported by China Dairy Cow Industry and Technology System (CARS-37), and China Infrastructure of Domestic Animal Resources.

\section{Competing Interests}

The authors have declared that no competing interests exist.

\section{References}

[1] China Committee on Animal Genetic Resources (2011) Animal Genetic Resources in China: Bovines. China Agriculture Press, Beijing, 218-221.

[2] Montaldo, H.H., Castillo-Juárez, H., Valencia-Posadas, M., Cienfuegos-Rivas, E.G. and Ruiz-López, F.J. (2010) Genetic and Environmental Parameters for Milk Production, Udder Health, and Fertility Traits in Mexican Holstein Cows. Journal of Dairy Science, 93, 2168-2175. https://doi.org/10.3168/jds.2009-2050

[3] Zhang, Y., Li, J.Q., Chen, Y.S., Zhang, Q., Zhang, L.L. and Pan, Y.C. (2001) Animal Breeding. China Agriculture Press, Beijing, 145-172.

[4] Mark, T. (2004) Applied Genetic Evaluations for Production and Functional Traits in Dairy Cattle. Journal of Dairy Science, 87, 2641-2652. https://doi.org/10.3168/jds.S0022-0302(04)73390-1

[5] VanRaden, P.M. (2004) Invited Review: Selection on Net Merit to Improve Lifetime Profit. Journal of Dairy Science, 87, 3125-3131. https://doi.org/10.3168/jds.S0022-0302(04)73447-5

[6] Wolfova, M., Wolf, J., Kvapil, K.J. and Kica, J. (2007) Selection for Profit in Cattle: II. Economic Weights for Dairy and Beef Sires in Crossbreeding Systems. Journal of 
Dairy Science, 90, 2456-2467. https://doi.org/10.3168/jds.2006-615

[7] Dekkers, J.C. and Gibson, J.P. (1998) Applying Breeding Objectives to Dairy Cattle Improvement. Journal of Dairy Science, 81, 19-35. https://doi.org/10.3168/jds.S0022-0302(98)70151-1

[8] Flores, E.B., Kinghorn, B.P. and van der Werf, J. (2013) Predicting Lactation Yields in Dairy Buffaloes by Interpolation and Multiple Trait Prediction. Livestock Science, 151, 97-107. https://doi.org/10.1016/j.livsci.2012.10.017

[9] ICAR (2010) ICAR Rules, Standards and Guidelines for Dairy Production Recording. In: International Committee on Animal Recording, International Agreement of Recording Practices, Section 2:23, International Committee on Animal Recording, Riga, Latvia.

[10] Fu, X.F., Wang, Y.C., Guo, J.Q., Guo, Z.Q., Cheng, L.M., Zhou, G.R., Huang, X.X. and $\mathrm{Xu}, \mathrm{Y}$. (2010) Study of Adjustment Factors for Standardizing Milking Records in Xinjiang Brown Cattle. Acta Veterinaria et Zootechnica Sinica, 41, 536-542.

[11] Boldman, K.G., Kriese, L.A., van Vleck, L.D., van Tassell, C.P. and Kachuman, S.D. (1995) A Manual for Use of MTDFREML. A Set of Programs to Obtain Estimates of Variances and Covariances [DRAFT]. US Department of Agriculture, Agricultural Research Service.

[12] Yener, S.M. (1979) Genetic Trends of Milk Yield in Brown Swiss Raised in Central Anatolian State Farms. PhD Thesis, Ankara Üniv Zir Fak, Ankara, 130.

[13] Akbulut, Ö. (1990) Milk Yield Traits and Factors Affecting Parameters of Lactation Curve of Brown Swiss, Brown Swiss Crosses and Holstein Friesian Raised in Atatürk University Farm. PhD Thesis, Atatürk Üniv Fen Bil Enst, Atatürk, 156.

[14] Doğan, I. and Ertuğrul, O. (1999) Heritability Estimation of Milk Production of Cows of Different Origin and Breed in Karacabey State Farm. Turkish Journal of Veterinary and Animal Sciences, 23, 26-33.

[15] Galip, B., Ali, K. and Hasan, Ü. (2004) Estimates of Genetic Parameters of Milk Yield in Brown Swiss and Holstein Friesian Cattle. Pakistan Journal of Biological Sciences, 7, 1198-1201.

[16] Meinert, T.R., Korver, S. and van Arendonk, J.A.M. (1989) Parameter Estimation of Milk Yield and Composition for 305 Days and Peak Production. Journal of Dairy Science, 72, 1534-1539. https://doi.org/10.3168/jds.S0022-0302(89)79264-X

[17] Santus, E.C., Everett, R.W., Quaas, R.L. and Galton, D.M. (1993) Genetic Parameters of Italian Brown Swiss for Levels of Herd Yield. Journal of Dairy Science, 76, 3594-3600. https://doi.org/10.3168/jds.S0022-0302(93)77699-7

[18] Zulkadir, U. and Aytekin, I. (2009) Genetic Analysis of Test Day Milk Yields of Brown Swiss Cattle Raised at Konuklar State Farm in Turkey, Using MTDFREML. South African Journal of Animal Science, 39, 10-14. https://doi.org/10.4314/sajas.v39i1.43540

[19] Yilmaz, I., Eyduran, E., Kaygisiz, A. and Javed, K. (2011) Estimates of Genetic Parameters for Lactation Shape Parameters with Multivariate Statistical Technique in Brown Swiss Cattle. International Journal of Agriculture and Biology, 13, 174-178.

[20] Tuna, Y.T. (2004) Studies on the Genetic Constitution of Black and White Dairy Cattle Raised in Tahirova State Farm. Pakistan Journal of Biological Sciences, 7, 931-933. https://doi.org/10.3923/pjbs.2004.931.933

[21] Atashi, H., Moradi, S.M. and Abdolmohammadi, A. (2006) Study of Suggested Measures of Milk Yield Persistency and Their Relationships. International Journal of Agriculture and Biology, 8, 387-390.

[22] Guler, O., Yanar, M. and Akbulut, O. (2010) Variance Component Estimation for 
Heritability of Gamma Lactation Curve Traits of Holstein Friesian Cattle. The Indian Veterinary Journal, 87, 35-38.

[23] Süleyman, Ç. and Ali, K. (2008) Breeding Value Estimation of Dairy Cattle Using Test Day Milk Yields for Brown Swiss Cows Reared at Ulaş State Farm. Journal of Animal and Veterinary Advances, 7, 703-706.

[24] Muammer, T., Mehmet, Ç. and Mehmet, S. (2009) Genetic Parameters of 305-Day Milk Yield for Brown Swiss Reared in the Bahri Dağdaş International Agricultural Research Institute in Turkey. Kafkas Univ Vet Fak Derg, 15, 397-400.

[25] De Roos, A.P.W., Harbers, A.G.F. and de Jong, G. (2004) Random Herd Curves in a Test-Day Model for Milk, Fat, and Protein Production of Dairy Cattle in the Netherlands. Journal of Dairy Science, 87, 2693-2701. https://doi.org/10.3168/jds.S0022-0302(04)73396-2

[26] Bohmanova, J., Miglior, F. and Jamrozik, J. (2009) Use of Test-Day Records beyond Three Hundred Five Days for Estimation of Three Hundred Five-Day Breeding Values for Production Traits and Somatic Cell Score of Canadian Holsteins. Journal of Dairy Science, 92, 5314-5325. https://doi.org/10.3168/jds.2009-2280

[27] Çilek, S. and Tekin M.E. (2006) Calculation of Adjustment Factors for Standardizing Lactations to Mature Age and 305-Day and Estimation of Heritability and Repeatability of Standardized Milk Yield of Simmental Cattle Reared on Kazova State Farm. Turkish Journal of Veterinary and Animal Sciences, 30, 283-289.

[28] Van Raden, P.M., Sanders, A.H., Tooker, M.E., Miller, R.H., Norman, H.D., Kuhn, M.T. and Wiggans, G.R. (2004) Development of a National Genetic Evaluation for Cow Fertility. Journal of Dairy Science, 87, 2285-2292. https://doi.org/10.3168/jds.S0022-0302(04)70049-1

[29] Haile-Mariam, M., Carrick, M.J. and Goddard, M.E. (2008) Genotype by Environment Interaction for Fertility, Survival, and Milk Production Traits in Australian Dairy Cattle. Journal of Dairy Science, 91, 4840-4853. https://doi.org/10.3168/jds.2008-1084

[30] Olori, V.E., Meuwissen, T.H.E. and Verkamp, R.F. (2002) Calving Interval and Survival Breeding Values as Measure of Cow Fertility in a Pasture-Based Production System with Seasonal Calving. Journal of Dairy Science, 85, 689-696. https://doi.org/10.3168/jds.S0022-0302(02)74125-8

[31] Wall, E., Brotherstone, S., Woolliams, J.A., Banos, G. and Coffey, M.P. (2003) Genetic Evaluation of Fertility Using Direct and Correlated Traits. Journal of Dairy Science, 86, 4093-4102. https://doi.org/10.3168/jds.S0022-0302(03)74023-5

[32] Haile-Mariam, M., Bowman, P.J. and Goddard, M.E. (2003) Genetic and Environmental Relationship among Calving Interval, Survival, Persistency of Milk Yield and Somatic Cell Count in Dairy Cattle. Livestock Production Science, 80, 189-200. https://doi.org/10.1016/S0301-6226(02)00188-4

[33] González-Recio, O. and Alenda, R. (2005) Genetic Parameters for Female Fertility Traits and a Fertility Index in Spanish Dairy Cattle. Journal of Dairy Science, 88, 3282-3289. https://doi.org/10.3168/jds.S0022-0302(05)73011-3

[34] Pryce, J.E. and Veerkamp, R.F. (2001) The Incorporation of Fertility Indices in Genetic Improvement Programmes. In: Diskin, M.G., Ed., Fertility in the High-Producing Dairy Cow, Vol. 1, British Society of Animal Science, Scotland, 237-250.

[35] Kadarmideen, H.N., Thompson, R., Coffey, M.P. and Kossaibati, M.A. (2003) Genetic Parameters and Evaluations from Single- and Multiple-Trait Analysis of Dairy Cow Fertility and Milk Production. Livestock Production Science, 81, 183-195. https://doi.org/10.1016/S0301-6226(02)00274-9 
[36] Grosshans, T., Xu, Z.Z., Burton, L.J., Johnson, D.L. and Macmillan, K.L. (1997) Performance and Genetic Parameters for Fertility of Seasonal Dairy Cows in New Zealand. Livestock Production Science, 51, 41-51. https://doi.org/10.1016/S0301-6226(97)00104-8

[37] Fu, X.F., Cheng, L.M., Guo, J.Q., Li, W.Y., Jia, X.S., Guo, Z.Q., Zhou, G.R. and Huang, X.X. (2010) Analysis of Non-Genetic Factors Influencing Milk Yield in Xinjiang Brown Cattle. Animal Husbandry \& Veterinary Medicine, 42, 41-44.

Submit or recommend next manuscript to SCIRP and we will provide best service for you:

Accepting pre-submission inquiries through Email, Facebook, LinkedIn, Twitter, etc. A wide selection of journals (inclusive of 9 subjects, more than 200 journals) Providing 24-hour high-quality service User-friendly online submission system Fair and swift peer-review system Efficient typesetting and proofreading procedure Display of the result of downloads and visits, as well as the number of cited articles Maximum dissemination of your research work

Submit your manuscript at: http://papersubmission.scirp.org/ Orcontact as@scirp.org 